\title{
Üretimde İthal Girdi Kullanımı Üzerine Firma Düzeyinde Bir Araştırma: Denizli Tekstil ve Hazır Giyim Sektörü Örneği*
}

\section{A Firm-Level Research on Imported Input Use in Production: Denizli Textile and Apparel Sector Case}

\author{
Burcu Sabaz a , Mustafa Terzioğlu ${ }^{\text {b,** }}$ \\ ${ }^{a}$ Muğla Sıtkı Koçman Üniversitesi, Sosyal Bilimler Enstitüsü, İktisat Anabilim Dalı, Muğla /Türkiye. \\ ORCID: 0000-0002-3591-6823 \\ ${ }^{\text {b }}$ Dr. Öğr. Üyesi, Muğla Sıtkı Koçman Üniversitesi, İktisat Bölümü, Muğla /Türkiye. \\ ORCID: 0000-0002-7314-0149
}

\begin{tabular}{l} 
MAKALE BİLGİS \\
Makale Geçmişi: \\
Başvuru tarihi: 08 Kasım 2019 \\
Düzeltme tarihi: 07 Haziran 2020 \\
Kabul tarihi: 15 Haziran 2020 \\
\hline Anahtar Kelimeler: \\
İthal girdi kullanımı \\
Tekstil ve hazır giyim sektörü \\
Alan araştırması \\
Denizli
\end{tabular}

\section{ÖZ}

Bu çalışmada, tekstil ve hazır giyim sektöründe ithal girdi kullanımının düzeyi ve nedenleri alan araştırması yöntemiyle Denizli özelinde incelenmiştir. Üretimde kullanılan girdiler hammadde, ara malı ve yatırım malı olarak gruplandırılmıştır. 86 firmadan elde edilen verilere göre, ithal girdi kullanım oranı iplik, pamuk ve elyafta ortalama \% 67 olarak hesaplanmıştır. Ara malı grubunda ithal girdi kullanım payı yok denecek kadar azdır. Makine ve teçhizat grubunun ise neredeyse tamamının ithal edildiği tespit edilmiştir. Girdilerde ithalat payının teknik olarak üretilemeyen girdilerle (makineler) birlikte, belli bir dönem önce üretilen ancak maliyet ve fiyat baskıları nedeniyle üretmekten vazgeçilen (pamuk, iplik gibi) alanlara da yayılması, ekonomi politikaları açısından düşündürücüdür. Bu nedenle, ekonomi politikalarının gözden geçirilmesi kaçınılmazdır.

\section{ART ICLE INFO}

\section{Article history:}

Received 08 November 2019

Received in revised form 07 June 2020

Accepted 15 June 2020

\section{Keywords:}

Use of imported input

Textile and apparel sector

Field survey

Denizli.

\begin{abstract}
A B S T R A C T
In this study, the level and reasons of the use of imported inputs in textile and apparel sector have been investigated in Denizli by field research method. The inputs used in production are grouped as raw materials, intermediate and investment goods. According to the data obtained from 86 companies, the ratio of imported input use was calculated as $67 \%$ in yarn, cotton and fiber. In the intermediate goods group, the share of imported input use is almost negligible. It was determined that almost all of the machinery and equipment group were imported. The fact that the share of imports in the inputs is spread to the fields that are not technically produced (machinery), but which were produced a certain time ago but abandoned to produce due to cost and price pressures (cotton, yarn) is thought-provoking in terms of economic policies. Therefore, the revision of economic policies is inevitable.
\end{abstract}

\section{Giriş}

Son yıllarda dünya ticaretinde küresel çapta yaşanan diş ticaret imkanlarını kolaylaştırıcı gelişmeler ülkeler arası ürünlerin, sermayenin ve işgücünün serbest dolaşımına imkân tanırken, uluslararası rekabeti de iyice artırmaktadır (Baldwin, 2006). İhracatçı firmalar ile yurt dışındaki firmalar arasında, yerel piyasaya dönük firmalar ile yurt içindeki firmalar arasında kıyasıya bir rekabet söz konusudur. Teknolojik yatırımlarla yenilikler yaratarak, rakiplerine göre farklılık yaratmak veya ürünlerini rakiplerine göre daha düşük fiyattan piyasaya sürmek rekabet gücü kazanmak için uygulanabilecek alternatif politikalar arasında yer almaktadır. Ancak firmalar,

\footnotetext{
*Bu çalışma, birinci yazarın 2018 yılında Dr. Öğr. Üyesi Mustafa Terzioğlu danışmanlığında Muğla Sıtkı Koçman Üniversitesi Sosyal Bilimler Enstitüsü İktisat Anabilim Dalı'nda tamamladığı ve Bilimsel Araştırmalar Koordinasyon Birimi tarafından Araştırma Projesi kapsamında 17/117 proje numarası ile desteklenen “Tekstil Sektöründe İthal Girdi Bağımlılı̆̆ı: Denizli Örneği” başlıklı yüksek lisans tezinden türetilmiștir.

** Sorumlu yazar/Corresponding author. e-posta: mterzioglu@ mu.edu.tr
} 
ekonomik performanslarını artırabilmek veya piyasalarda tutunabilmek için gerek firma gerekse ülke düzeyinde sahip oldukları donanım ve imkanlar dahilinde politikalar üretebilmektedirler. Ülkenin ve firmanın sahip olduğu nitelikli işgücü, enerji kaynakları gibi üretim faktörlerinin ve araştırma-geliştirme (Ar-Ge), yenilik faaliyetleri gibi teknoloji kapasitesinin düzeyi belirlenecek politikayı doğrudan etkilemektedir.

Dış ticareti kolaylaştırıcı gelişmeler diğer taraftan dünya ticaret hacmini hızlı bir şekilde artırmıştır. Örneğin dünya ticaretinde ara mallarının payı giderek artmıştır. Ayrıca bir ürünün üretim sürecindeki neredeyse her aşama farklı bir ülkelerde tamamlanır hale gelmiştir. Yani, bir ürünün ana parça ve alt bileşenleri farklı ülkelerdeki ana firmaya bağlı veya bağlı olmayan üreticiler tarafindan üretilebilmektedir. $\mathrm{Bu}$ durum ülke ekonomisine doğrudan ve dolaylı birçok etkiye neden olmaktadır (Blinder, 2009; Baldwin, 2009; Akçomak, 2012). Öte yandan bir hammaddenin fiyatı üretim yeri ile nihai piyasa arasındaki her bir aşamada çeşitli ek girdi ve katma değer unsurları eklenerek yükselmektedir (Boratav, 2013). Küresel üretim zinciri diye de kavramlaştırılan bu süreçte yer alan ülkelerin üretime yaptığı katkı farklı olabilmektedir. Teknoloji kapasitesi yüksek ülkeler üretimin katma değeri yüksek aşamalarında yer alırken, düşük olanlar da katma değeri düşük aşamalarında yer alabilmektedirler. Türkiye'deki firmaların Ar-Ge ve yenilik kapasitesi üzerine yapılmış çalışmalarda firmaların büyük bir kısmının bu alanda yetersiz olduğu görülmektedir. $\mathrm{Bu}$ nedenle Türkiye'deki firmaların büyük bir kısmı küresel üretim zincirinde katma değeri düşük aşamalarda rol almaktadır (Taymaz vd., 2011). Dahası, Türkiye imalat sanayi katma değerinin \% 69,8'inin düşük ve düşük-orta teknolojili sektörlerde yaratıldığı bilinmektedir (Eşiyok, 2013). Bu durumun iyileştirilmesi için Türkiye'deki firmaların teknoloji ve yenilik kapasitelerinin genele yayılabilecek şekilde yükseltilmesi gerekmektedir. $\mathrm{Bu}$ da mevcut koşullarda oldukça uzun sayılabilecek bir dönemde gerçekleşebilecektir.

Dolayısıyla Türkiye'deki firmaların büyük bir kısmı için fiyat rekabeti kaçınılmaz bir politika haline gelmektedir. Firmaların fiyat rekabetinde avantaj kazanmaları için maliyetlerini olabildiğince minimize etmeleri gerekmektedir. $\mathrm{Bu}$ da üretimde kullanılan girdilerin maliyetinin önemini artırmaktadır. Bu doğrultuda firmalar, yerel girdi üretiminin yetersizliği, yerel üretim maliyetlerinin yüksekliği nedeniyle yerel girdi fiyatlarının yüksek olması, yerel girdilerin kalitesinin yetersiz olması, uygulanan döviz kuru politikası gibi birçok nedenle yerli girdiden daha çok ithal girdi kullanımına yönelmektedirler. $\mathrm{Bu}$ nedenle üretimde kullanılan ithal girdi payı yüksek olmaktadır. İthal girdi kullanımının yüksekliği ithalatın mal gruplarına göre dağılımına da yansımıştır. Türkiye'de ithalatın mal gruplarına göre dağılımı incelendiğinde, 2017 yılı itibariyle \% 73'ünün ara malı olduğu görülmektedir (TCSBB, 2019). Bu oran ilk bakışta da üretimde ithal girdi kullanım payının yüksekliği ile ilgili şüphe uyandırmaktadır. $\mathrm{Bu}$ konuda Türkiye için yapılan çalışmalardan elde edilen bulgular ise şüphelerin gerçek olduğunu kanıtlar niteliktedir. Ayrıca çalışmalarda Türkiye imalat sanayinde ithal girdi kullanım payının son yıllarda giderek arttığı vurgulanmaktadır. Bu aşamada yerel girdi üretiminin teşvik edilmesi diş ticaret dengesi üzerine doğrudan olumlu etki, istihdam, gelir, yatırım, vergi gelirleri alanlarında da dolaylı olumlu etki söz konusu olacaktır. Ayrıca Ar-Ge ve yenilik odaklı üretim politikasına göre daha kısa vadeli etkiler yaratabileceği açıktır.

Türkiye'de ithal girdi kullanımı üzerine birçok çalışma söz konusudur. Ancak bu çalışmalar genellikle girdi-çıktı tabloları kullanılarak yapılmış olup, firma ve sektör düzeyinde yapılan çalışma sayısı oldukça sınırlıdır. Ayrıca girdi-çıktı tablolarının güncel olmaması yakın geçmişteki gelişmeleri tespit etme imkanını ortadan kaldırmaktadır. Bu nedenle, firma ve sektör düzeyinde yapılan çalışmaların önemi, güncel sektörel ithal girdi kullanım oranlarının ve nedenlerinin belirlenmesi ve bu tespitler doğrultusunda sektörel politikaların belirlenmesi açısından oldukça yüksektir. $\mathrm{Bu}$ nedenle bu çalışmada, imalat sanayi alt sektörlerinden tekstil ve hazır giyim sektöründe ithal girdi kullanım oranlarını ve bunun nedenlerini tespit etmek amacıyla Denizli özelinde alan araştırması yapılmıştır. Üretimde kullanılan girdiler, hammadde (pamuk, elyaf, iplik gibi), ara malı (boyar madde ve ağartıcılar gibi) ve yatırım malları (dokuma, boyama makineleri gibi) olarak üç grupta değerlendirilmiştir. Sektör için genel bir ithal girdi oranı hesaplamak yerine mal grupları itibariyle oranları belirlemek ve ithal etme nedenlerini ayrı ayrı tespit etmek amaçlanmıştır.

\section{Literatür Araştırması}

Bir ürünün üretimin ilk aşamasından nihai ürün haline kadar geçen süreçte birçok ülkeye girip çıkması dış ticaret değerlerini olduğundan fazla göstermektedir. $\mathrm{Bu}$ nedenle uluslararası literatürde üretimdeki yerel ve dış katkıyı belirlemek amacıyla dikey uzmanlaşma yöntemi Hummels vd. (2001) tarafindan geliştirilmiştir. Bu ve bunu takip eden çalışmalarda ülkelerdeki ithal girdi kullanımı katma değer üzerinden belirlenmektedir. Üretimdeki katma değer girdiçıktı tabloları kullanılarak yerel ve yabancı olmak üzere ikiye ayrıştırılmaktadır.

Hummels vd. (2001) yerel ve yabancı katkıyı OECD girdiçıktı veri tabanını kullanarak, dünya ticaretinin \% 60'ından fazlasını gerçekleştiren 10 OECD ülkesi ve 4 yükselen ekonomi ülkeleri için kendilerinin geliştirdiği HIY yöntemi ile incelemişlerdir. OECD ülkeleri için 1990 yılında mal üretiminde ihracatta ithal girdi payının ortalama $\% 20$ olduğunu, küçük ekonomiler için bu oranın \% 40 olduğunu hesaplamışlardır. Ayrıca, 14 ülke için yabancı katma değer payının 1970-1990 yılları arasında $\% 30$ arttığını hesaplamışlardır.

Chen vd. (2004) Çin için yaptıkları çalışmalarında ihracatı fason ve doğrudan ihracat olarak iki başlıkta değerlendirmişlerdir. ABD'ye yönelik yapılan fason ihracat sürecinde yerel katkı payının 1992 yılında \% 10 olduğunu, bu oranın 1995 yılında \% 20'ye ve 1999'da \% 35 çıktığını belirtmişlerdir. Kendi analizleri doğrultusunda fason ihracat kapsamında doğrudan etki bakımından en düşük yerel girdi kullanan sektörün \% 11,5 ile makine sanayi, en yükseğinin ise $\% 45,7$ ile finans ve sigortacılık olduğunu tespit etmişlerdir. Ayrıca toplam etki (doğrudan ve dolaylı etkiler) bakımından yerel girdi kullanımının en yüksek olduğu sektörün \% 96,4 ile tarım sektörü olduğunu ve en düşüğünün \% 85,1 ile ulaşım araçları sektörü olduğunu hesaplamışlardır. 
Koopman vd. (2012), kendilerinin geliştirdikleri KWW yöntemiyle Çin için yaptıkları çalışmada imalat sanayi ihracatında yabancı katma değer oranını 1999 yılı için \% 50 ve 2007 yılı için \% 40 olarak hesaplamışlardır. Bu oranlar alt sektörler bazında hesaplanmış olup tekstil ve hazır giyim sektörü olarak toplulaştırıldığında yabancı katma değer payının yaklaşık \% 30 olduğu görülmektedir. Ayrıca çalışmada, aynı verilerle HIY yöntemiyle hesaplanan yabancı katma değer oranının (1999 için \% 19, 2006 için \% 27) KWW yöntemi bulgularından daha düşük olduğu ve KWW yöntemi bulgularının daha gerçekçi olduğu vurgulanmıştır.

Babahanoğlu (2015), Türkiye için ilk kapsamlı çalışmayı Koopman vd. (2012) tarafindan geliştirilen yöntemi kullanarak, 2005-2011 döneminde ihracattaki yerli ve yabancı katma değeri ayrıştırarak yapmıştır. Yerel katma değer payı ortalama \% 80 olarak hesaplanmıştır. Analiz bulgularına göre tekstil ve deri sektörleri dışındaki sektörlerde, ihracattaki yerel katma değer payında 2008 yılına kadar yükseliş ve sonrasında düşüş görülmüştür. Tekstil ve tekstil ürünleri sektörünün ihracatındaki yerel katma değer payında 2006-2011 döneminde sürekli bir düşüş görülmesi, bu sektörü diğerlerinden farklı kılmaktadır. Bu sektörde yerel katma değer payı ilgili dönemde $\% 78$ 'den \% 72'ye düşmüştür.

Türkiye için girdi-çıktı tabloları kullanılarak yabancı ve yerli girdi kullanımı birçok çalışmada hesaplanmıştır (Pamukçu ve de Boer, 2000; Şenesen ve Güllük Şenesen, 2003; Yentürk, 2004; Ersungur ve Kizıltan, 2007; Yükseler ve Türkan, 2006; Aydoğuş, vd. 2015; Ayaş, 2017). Bunun yansıra bu konuyu alan araştırması yöntemiyle veya firma düzeyindeki verilerle araştıran çalışma ise yok denecek kadar azdır (Türkan, 2006; Saygılı vd., 2010). Pamukçu ve de Boer (2000), 1968-1990 yılları arasında Türkiye'nin ithalatının kaynaklarını inceledikleri çalışmalarında yapısal ayrıştırma yöntemini kullanmışlardır. Analiz için Türkiye'nin 1968, 1973, 1979, 1985 ve 1990 girdi-çıktı tablolarından hareketle, ithal ikameci sanayileşme politikaların uygulandığı dönem (1968-1979) ile ihracata dayalı sanayileşme politikalarının uygulandığı dönemi (1980-1990) karşılaştırmışlardır. Analiz bulgularına göre, 1980-1990 dönemi boyunca ara ve yatırım malları ithalatındaki artışın temel sebebinin yurt içi talepteki artış olduğunu tespit etmişlerdir. Ancak dönemler arası karşılaştırma kapsamında tarım, tekstil ve gida sektörlerinde yaşanan ihracat artışının ithalat artışı ile desteklendiği ve ikinci dönemdeki ithal girdilerde yaşanan artışta teknoloji alanındaki gelişmelerin ve değişikliklerin önemli oranda katkısının bulunduğunu tespit etmişlerdir.

Şenesen ve Güllük Şenesen (2003) üretimin ithalata bağımlılığını, 1980'li yıllarda yaşanan yapısal değişimin etkilerini de dikkate alarak araştırmışlardır. Bu amaçla, 1973, 1985 ve 1996 yıllarına ait girdi-çıktı tabloları kullanılmış ve özellikle enerji sektöründe ve teknoloji yaratılmasında dişa bağımlılığın 1980 sonrasında daha yüksek oranlara ulaştığını belirtmişlerdir. Ayrıca, Türkiye'nin lider sektörleri sayılan tekstil ve gıda sektörlerinde bile ithalata bağımlılığın gittikçe arttığını vurgulamışlardır.

Yükseler ve Türkan (2006), ithal girdi bağımlılığını 1998 yılına ait girdi-çıktı tablosunu kullanarak analiz etmişlerdir. Bulgulara göre, doğrudan ve dolaylı ithal girdi payının imalat sanayi geneli için ortalama \%21,89 olduğu sonucuna ulaşılmıştır. Sıralamaya göre ana metal alt sektörü \%35,7'lik pay ile ilk sırada yer almaktadır. Ardından, kimyasal madde ürünleri, elektrikli makine ve cihazlar, plastik ve kauçuk ürünleri alt sektörleri gelmektedir. Bu sektörlerde ithal girdi payının imalat sanayi genel ortalamasının önemli ölçüde üzerinde olduğunu gözlenmektedir. En düşük ithal girdi payı \%11,2 ile gıda ve içecek ürünleri sektörüne aittir. Bu oran, metalik olmayan diğer mineral ürünler sırasıyla, ağaç mantar ürünleri ve tütün ürünleri sektörlerinde sirasıyla yükselmektedir. İthal girdi payı tekstil sektörü için \%20,4 ve hazır giyim sektörü için \%22,1 olarak hesaplanmıştır.

Konak (2012), çalışmasında 1985, 1990,1998 ve 2002 yıllarında hazırlanan girdi-çıktı tabloları ile ithal girdi bağımlığını belirlemektedir. 1985 yılında ilk 5 sektörlerden birinin tarım sektörü iken 1990, 19982002 yıllarında ilk 5 sektörün (madencilik, dokuma ve deri, kimya, ana metal sanayi ve elektrikli makineler) aynı sektör olduğunu, ancak bu sektörlerin önem sıralarının değiştiği sonucuna ulaşmıştır. 2002 yılından sonraki dönemde 2003-2010 yılına kadar girdi- çıktı tablolarından yararlanarak hazırlanan ihracat/toplam üretim oranı ile ihracat/ toplam arz oranları kullanılmıştır. 2010 yılı itibaren bağımlılığı yüksek olan sektörler radyo, televizyon, haberleşme teçhizatı ve cihazları sektörü olduğu tespit edilmiştir. Bu sektörlerin ardından ana metal sanayi, metal eşya sanayi, kimyasal madde ve ürünler, tekstil ürünleri, plastik ve kauçuk ürünleri sektörleri gelmektedir.

Yalçın vd. (2015), imalat sanayi y1llık anketleri, gümrük veri tabanı ve girdi-çıktı tablolarını kullandıkları çalışmalarında, alt-sektörlerdeki ithal ve yerli girdi kullanımlarını toplam gelirlerin yüzdesi olarak hesaplamışlardır. Buna göre, imalat sanayinde ithal girdi kullanım oranı ortalama \% 37,7 olarak hesaplanmıştır. Bu oran tekstil ürünleri sektöründe $\% 31,1$ iken giyim eşyası sektöründe \% 13 'tür.

Alan araştırması ile firma düzeyinde yapılan çalışmalardan en kapsamlısı Saygılı vd. (2010) tarafindan, imalat sanayinde faaliyet gösteren görece büyük ölçekli, kurumsallaşmış ve küresel ticaret sistemine katılım düzeyi yüksek olan 145 firmayla (imalat sanayinin sektörel üretim yapısına paralel olarak, ağırlıkla makine-teçhizat, bilgisayar-elektronik-optik, tekstil-giyim-deri, petrol ve kimya ile motorlu kara taşıtları sektörleri) yüz yüze görüşerek yapılmıştır. Alan araştırmasının yanı sıra girdiçıktı tablolarından da yararlanılmıştır. Yapılan analizler sonucunda imalat sanayi genelinde toplam hammadde ve malzeme içerisindeki ithalat payının 2002 yılında \% 56,5 olduğu, bu değerin kısa bir süre sonra 2007 yılında \% 61,8 'e yükseldiği tespit edilmiştir. Sanayi sektörlerinin neredeyse tamaminda üretimde kullanılan ithal girdi oranında artış meydana geldiği belirtilmiştir. Tekstil, giyim ve deri sektöründe 2002 yılında hammadde ve malzeme içerisindekindeki ithalat payı \% 45,5 iken, bu oranın 2007 yılında \% 50,5'e yükseldiği tespit edilmiştir.

Türkan (2006), hisse senedi piyasasında işlem gören ve imalat sanayinde faaliyet gösteren 170 firmaya ait verileri kullanarak, 2003-2005 döneminde üretimin ihracata ve ithalata bağımlılığını hesaplanmıştır. Hazır giyim sektöründe ithalatın maliyetler içindeki payının 2003, 2004 ve 2005 yillarında sirasıyla $\% 41,8, \% 52,4$ ve $\% 42,8$ olduğu, 
tekstil sektöründe ise bu oranın aynı dönem için \%41,2, $\% 39,8$ ve $\% 40,7$ olduğu hesaplanmıştır.

Özlale ve Karakurt (2012) çalışmalarında imalat sanayi sektörlerinin ithalata bağımlılık oranını 2008-2011 dönemi için hesaplamışlardır. Buna göre, ithalat bağımlılık oranının yüksek olduğu sektörleri, gübre üretimi (\%72), demir-çelik (\%69), bilgisayar ve veri işleme makineleri (\%67), kimya $(\% 56)$, diğer metaller ve mamuller $(\% 51)$ ve motorlu kara taşıtları (\%51) sektörleri olduğu tespit edilirken, görece düşük olan sektörlerin hayvancılık ürünleri $(\% 16)$, diğer gida \% (12), mobilya (\%11), içecek imalatı (\%10), sebzemeyve $(\% 9)$ ve tütün ürünleri $(\% 8)$ sektörleri olduğu tespit edilmiştir. Bu oranın tekstil sektöründe $\% 43$ ve hazır giyim sektöründe ise \%19 olduğu hesaplanmıştır.

Kundak (2015) çalışmasında, Türkiye'de imalat sanayi alt sektörlerinin ithalata bağımlılı̆̆ını, 1996-2011 yıllarını kapsayan dönem için dinamik panel veri analizi yöntemiyle araştırmıştır. Elde edilen sonuçlara göre, döviz kurunda meydana gelen artışların imalat sanayi ithalat bağımlılığını kısa dönemde azalttığı, ancak uzun dönemde ise arttırdığı bulgusuna ulaşmışlardır. Uzun dönemde bu ilişkinin temelinde ara mallarında ithalata bağımlılığın yüksek olması yer almaktadır.

Çolak ve Terzioğlu (2019), çalışmalarında Türkiye imalat sanayinde 20 alt-sektörde ithalat ve ihracat arasındaki kısa ve uzun dönemli ilişkiyi 1996-2018 yıllarına ait verilerle panel veri yöntemi kapsamında PMG modeliyle tahmin etmişlerdir. Analiz bulgularına göre hem kısa hem de uzun dönemde ihracat ile ithalat arasında anlamlı ve güçlü bir ilişki tespit edilmiştir. İhracattaki \% 1'lik artışın ithalatı uzun dönemde \% 0,85 ve k1sa dönemde \% 0,52 artırdı ğ 1 , ortaya çıkan bir dengesizliğin yaklaşık 3 yıl içerisinde dengeye ulaştığı hesaplanmıştır. Hem kısa ve hem de uzun dönemde anlamlı ve güçlü ilişkinin söz konusu olduğu sektörler kimyasal madde ve ürünler, plastik ve kauçuk ürünleri, metal eşya, makine ve tekstil ürünleri sektörleridir. Tekstil ürünleri sektöründe kısa dönemde \% 1'lik ihracat artışı ithalatı \% 0,89 artırmaktadır. Ayrıca, kısa dönemli anlamlı ilişkiye sahip 11 sektör arasında büyüklük bakımından 3. sırada yer almaktadır. Bulgular sektördeki ithal girdi kullanımının yüksekliğine ve önemine işaret etmektedir.

\section{Yöntem ve Bulgular}

$\mathrm{Bu}$ çalışmanın amacı, Türkiye'de imalat sanayinin istihdam, üretim ve ihracat açısından önemli alt sektörlerinden biri olan tekstil ve hazır giyim sektöründe, ithal girdi kullanım alanlarını, düzeyini ve nedenlerini tespit ederek, ilgili sorunlara yönelik çözüm önerileri geliştirilmesine imkan tanımaktır. Tekstil ve hazır giyim sektörde ithal girdiyi azaltacak çalışmalara ağırlık verilirse, bu gelişme sektörün sadece ülke dış ticaretine katkısını artırmayacak, aynı zamanda ülke içinde yaratılan toplam istihdamı, üretimi ve katma değeri de olumlu yönde etkileyecektir. $\mathrm{Bu}$ amaçla çalışmada yanıt alınacak sorular şu şekildedir:

1.Tekstil ve hazır giyim sektöründe üretimde kullanılan hammadde, ara malı ve makine-teçhizatın ne kadarı ithal edilmektedir?
2.İthal edilen hammadde, ara malı ve makine-teçhizat hangi ülkelerden ithal edilmekte ve ithal edilme nedenleri nelerdir?

Bu doğrultuda Denizli ilinde imalat yapan tekstil ve hazır giyim sektöründeki firmalardan derinlemesine yüz yüze görüşme ve anket yöntemleri ile 86 firma ile görüşmeler yapılmıştır. Anket formunun 3 ana bölümü söz konusudur. İlk bölümde firmaların genel bilgilerini (satışları, öz sermayesi, çalışan sayıları, ihracat yapma oranları) ve maliyet yapılarını belirlemeye yönelik sorular bulunmaktadır. İkinci bölümde firmaların üretimde kullandığı girdilerin yerli ve ithal paylarını ve ithal edilenlerin ülkelerini belirlemeye yönelik sorular hammadde, ara malı ve makine-teçhizat grupları için ayrı ayrı sorulmaktadır. Üçüncü bölümde ise ithal girdi kullanımlarının nedenlerini belirlemeye yönelik sorular söz konusudur. Son olarak da sektörün sorunlarını anlamaya yönelik açık uçlu sorulara yer verilmiştir.

Firmalara temsilen görüşme yapılanların 44'ü işyeri sahibi, 32'si yönetici ve 10'u bölüm şefidir. Görüşmeler, 2018 yılının ilk 3 ayında gerçekleştirilmiştir.

\subsection{Firmalara Ait Genel Bilgiler}

Çalışma kapsamında yer alan tekstil ve hazır giyim firmalarının alt sektörleri iplik, ham bez dokuma, havlu dokuma, havlu-bornoz, konfeksiyon ve ev tekstili şeklindedir. Firmaların genel profillerine ait bilgilere Tablo 1 'de yer verilmiştir. Görüşmeye katılan firmaların ortalama yaşı 23'tür. $\mathrm{Bu}$ firmaların yaşları 2 ile 41 arasında değişmektedir. Çalışma kapsamında firmaların ortalama öz sermayesi yaklaşık olarak 5 milyon TL, bu firmaların öz sermayeleri 300 bin TL ile 100 milyon TL arasinda değişmektedir. Çalışma kapsamında yer alan firmaların yerli sermaye oranı \%94 olarak hesaplanmıştır. $\mathrm{Bu}$ firmaların ortalama satışı 41 milyon TL iken bu değer 100 bin TL ile 210 milyon TL arasında değişmektedir.

Çalışma kapsamındaki firmaların ortalama çalışan sayısı 104 olarak hesaplanmıştır. $\mathrm{Bu}$ firmaların istihdamının kadın-erkek dağılımına bakıldığında, \%55,5'inin kadın, $\% 44,5$ 'inin ise erkek olduğu görülmektedir. Bu firmalarda çalışanların \%0,7'si Ar-Ge departmanında, \%8,9'u yönetim kademelerinde ve $\% 90,5$ 'i de üretimde çalışmaktadır. ArGe çalışanlarının düşük olmasının ana nedeni, bu firmaların büyük bir kısmının Ar-Ge departmanlarının olmamasıdır. $\mathrm{Bu}$ firmaların işgücüne ödenen ortalama ücret 2.352,20 TL olarak hesaplanmıştır. İstihdam edilenler arasında Ar-Ge'de çalışanların ortalama ücreti $3.811,538 \mathrm{TL}$, yönetimde çalışanların ortalama ücreti $2.881,618 \mathrm{TL}$ ve üretimde çalışanların ortalama ücreti $1.713,605$ TL olarak tespit edilmiştir.

Firmaların üretimden ihracat yapma oranı ortalama $\% 36,8$ olarak hesaplanmıștır. İhracat yapma oranın düșük olmasının en önemli nedeni olarak kaynak yetersizliği belirtilmiştir. İhracat yapan firmaların ihracat performansını etkileyen en önemli unsurun döviz kuru politikası olduğu anlaşılmaktadır. İkinci önemli olan unsur olarak ihracat teşviklerinin yetersiz olması ve küçük-orta ölçekli birçok firmanın bu teşviklerden yararlanamaması gösterilmiştir. 
Tablo 1. Çalışma kapsamında Firmalara Ait Genel Bilgiler

\begin{tabular}{lr}
\hline & \multicolumn{1}{c}{ Değerler } \\
\hline Ortalama firma yaşı & 23 \\
Ortalama öz sermaye (TL) & $4.868 .255,81$ \\
Ortalama satışlar (TL) & $32.272 .441,86$ \\
Ortalama çalışan sayısı & 104 \\
İşücüne ödenen ortalama ücret (TL) & $2.352,20$ \\
İhracat yapma oranı (\%) & 36,8 \\
\hline
\end{tabular}

Tablo 2'de firmaların katlandığı toplam maliyetlerin dağılımı yer almaktadır. Firmaların üretim için katlandığı maliyetler incelendiğinde, ilk sirayı \% 39 ile hammadde alırken, ardından \% 22,4 ile işçi ödemeleri, \% 12,2 ile gelir kurumlar vergi ödemeleri, \% 10,9 ile enerji giderleri, \% 5,4 yenilenme giderlerini, $\% 4,1$ ara malları gelmektedir.

Tablo 2. Görüşmeye Katılan Firmaların Katlandığı Maliyetlerin Dağılımı

\begin{tabular}{lc}
\hline Maliyetler & Değerler (\%) \\
\hline Hammadde & 39,0 \\
İşi Ödemeleri & 22,4 \\
Gelir ve Kurumlar Vergisi Ödemeleri & 12,2 \\
Enerji Giderleri & 10,9 \\
Kredi Faiz Giderleri & 6,0 \\
Yenileme Giderleri & 5,4 \\
Ara Mallar & 4,1 \\
\hline
\end{tabular}

3.2. Firmaların Üretimde Kullandıkları Girdilerde İthal Kullanım Payları ve İthal Kullanım Nedenlerine İlişkin Bilgiler

Çalışma kapsamında firmaların üretimde kullandıkları girdiler hammadde, ara malı ve makine ve teçhizat olarak üçe ayrılmaktadır. Hammadde türünde pamuk, elyaf, iplik, kumaş; ara malı türünde boyar madde, kimyasal girdiler ağartıcılar, parlatıcılar, vb., diğer (fermuar, düğme, vb.) ve makine teçhizat türünde iplik üretim makineleri, kumaş üretim makineleri, ön terbiye makineleri, boyama makineleri, hazır giyim üretim makineleri olarak ayrilmaktadır.

Firmaların üretimde kullandıklarl hammaddelerde ithal kullanım:

Tablo 3'te firmaların hammadde türünde ithal kullanım payı yer almaktadır. Hammadde türlerine göre ithal girdi kullanım payları pamukta $\% 70$, iplikte $\% 79$, elyafta $\% 53$ ve kumaşta \%20 olarak hesaplanmıştır.

Tablo 3. Görüşmeye Katılan Firmaların Hammadde Türünde İthal Kullanım Payı

\begin{tabular}{lc}
\hline Girdi Türü & İthal Kullanım Payı (\%) \\
\hline Pamuk & 70 \\
Elyaf & 53 \\
İplik & 79 \\
Kumaş & 20 \\
\hline
\end{tabular}

Pamuk ithalatı yapan firmaların pamuk ithal ettiği ülkelerin başında ABD $(\% 44,2)$ gelirken, ardından sirasıyla Yunanistan $(\% 29,9)$, Brezilya $(\% 11,7)$, Özbekistan $(\% 4,5)$, Misır (\%3,9), Pakistan (\%1,3) gelmektedir. Pamuk ithalatının en önemli nedeni olarak ithal olanın daha kaliteli (özellikle ABD, Yunanistan pamuğu) olması gelirken ardından yurtiçi üretimin yetersiz olması ve yerel olanın fiyatının yüksek olması gelmektedir. Elyaf ithal edilen ülkeler arasında Çin, Türkmenistan ve Pakistan yer almaktadır. Elyaf ithal edilmesinin nedenleri sırasıyla, yurtiçi üretiminin yetersiz olması, ithal olanın daha ucuz olması, ithal olanın daha kaliteli olması, yurtiçi üretiminin olmaması ve yetersiz olmasıdır. Firmaların iplik ithal ettiği ülkeler arasında Türkmenistan $(\% 50,3)$, Pakistan $(\% 28,8)$, Özbekistan $(\% 5,7)$, Hindistan $(\% 5,6)$, Çin $(\% 5,1)$ ve Misır $(\% 4,5)$ yer almaktadır. İthal girdi kullanımının nedenleri önem siralamasına göre, ithal olanın daha ucuz olması, yurt içi üretiminin yetersiz olması, ithal olanın daha kaliteli olması ve yurtiçi üretiminin yeterli olmamasıdır. Firmaların kumaş ithal ettiği ülkeler Pakistan $(\% 77,4)$, Çin $(\% 11,3)$, Türkmenistan $(\% 8,1)$, Özbekistan $(\% 1,6)$, Tayland $(\% 1,62)$ 'dır. Kumaş ithalatının en önemli nedeni ithal olanın daha ucuz olmasıdır. Tüm girdilerdeki ithal etme nedenleri bir arada değerlendirildiğinde en önemli ithalat nedeni, ithal olanın daha ucuz olması, ikinci önemli nedeni yurtiçi üretiminin yetersiz olması ve üçüncü önemli nedeni ithal olanın daha kaliteli olmasıdır.

Firmaların üretimde kullandıkları ara mallarında ithal kullanım:

Çalışma kapsamında üretimde kullanılan ara girdi türleri boyar madde, kimyasal girdiler (ağartıcılar, parlatıcılar, vb.) ve diğer (fermuar, düğme, vb.) olmak üzere üçe ayrılmaktadır. $\mathrm{Bu}$ firmaların üretimde kullandıkları ara malların (ara girdi, hammadde harici üretimde kullanılan girdiler) menşeine göre ithal olanların payı, üretim ülkeleri ve ithal kullanım nedenlerine yönelik bilgiler paylaşılmaktadır.

Çalışma kapsamında firmaların üretimde kullandıkları ara malı ithalatı genel ortalama olarak \%4,1 olarak hesaplanmıştır. Ara malı ithalatı yapan firmalar genellikle istihdama göre büyük ölçekli firmalardır. Boyar madde ithal eden firmalar için (toplam firmalar içindeki payı \%7) ithal boyar madde kullanım payı \%21,6 olarak hesaplanmıştır. Kimyasal girdi ithal eden firmaların (toplam firmalar içindeki payı \%8,1) ithal kimyasal girdi kullanım payı \%24,3 olarak hesaplanmıştır. Boyar ve kimyasal madde ithal edilen sektörler havlu bornoz, konfeksiyon ve ev tekstili sektörleridir. Ara malı ithal edilen ülkeler ise Almanya $(\% 42,9)$, İtalya $(\% 34,3)$, Çin $(\% 17,1)$ ve Japonya $(\% 5,7)$ 'dır. Genel bir değerlendirme yapılırsa, firmaların üretimde kullandıkları ara malı maliyetinin toplam maliyetleri içindeki payının göreceli olarak (örneğin hammaddeye göre) düşük olması ve yerli üretimin göreceli olarak (örneğin pamuk ve ipliğe göre) daha yeterli olması, firmaları yerli ürün kullanmaya yönelten sebepler arasindadir.

\section{Firmaların üretimde kullandıkları yatırım mallarında ithal kullanım:}

Firmaların makine ve teçhizat türünden iplik üretim makinelerin ithal kullanım payı ortalama \%96,4 olarak hesaplanmıştır. Pamuk ithalatı yapan firmalar iplik üretim makineleri de ithal etmektedir. Bu firmaların iplik üretim makinesi ithal ettiği ülkelerin başında İtalya $(\% 93,9)$ gelmektedir. Ardından, Almanya $(\% 3,3)$ ve İsviçre $(\% 2,8)$ gelmektedir. İthal kullanımın en önemli nedeni yurtiçi üretiminin yetersiz olmasıdır. Kumaş üretim makinelerinde ithal kullanım payı \%96,9 olarak hesaplanmıştır. Kumaş 
üretim makineleri ithal edilen ülkeler Almanya $(\% 49,4)$, İtalya $(\% 30,4)$, Güney Kore $(\% 6,1)$, İsveç $(\% 3,8)$, Japonya $(\% 4,2)$, Belçika (\%3) ve Çin (\%3)'dir. İthal kullanımın en önemli nedeni ithal olanın daha ucuz olmasıdır. Ön terbiye makinelerinde ithalat pay1 \%95'tir. Ön terbiye makineleri Almanya (\%50) ve İtalya'dan (\%50) ithal edilmektedir. İthal kullanımın en önemli nedeni ithal olanın daha kaliteli olmasıdır. Boyama makinelerinde ithal kullanım payı \%93,4 olarak hesaplanmıştır. İthal edilen ülkeler Almanya (\%68) ve İtalya (\%32)'dır. İthal kullanımın en önemli nedeni ithal olanın daha kaliteli olmasıdır. Hazır giyim makinelerinde ithal kullanım payı \%90'dır. Hazır giyim makinelerinin ithal edildiği ülkeler Almanya $(\% 81,5)$, Japonya $(\% 7,9)$, İtalya $(\% 4,5)$, Danimarka $(\% 2,4)$, Belçika $(\% 1,3)$, İsveç $(\% 1,1)$ ve Çin $(\% 1,3)$ 'dir. İthal kullanımın en önemli nedeni yurtiçi üretimin olmamasıdır.

Tablo 4. Görüşmeye Katılan Firmaların Makine ve Teçhizat Türünde İthal Kullanım Payı

\begin{tabular}{lc}
\hline Makine ve teçhizat türü & $\begin{array}{c}\text { İthal kullanım payı } \\
(\%)\end{array}$ \\
\hline İplik üretim makineleri & 96,4 \\
Kumaş üretim makineleri & 96,9 \\
Ön terbiye makineleri & 95 \\
Boyama makineleri & 93,4 \\
Hazır giyim üretimi makineleri & 90 \\
\hline
\end{tabular}

\section{Sonuç}

Türkiye'de Cumhuriyet'in ilanından itibaren 1930-1946 (1938 yılı hariç) dönemi dışında sürekli dış ticaret açığı söz konusudur. Dış ticaret açığını azaltmak için ihracat ile ithalatın dengeli bir şekilde gelişmesi sağlanmalıdır. Bu nedenle ihracatı teşvik edici politikalar kadar ithalatı düzenleyici ve kontrol altına alıcı politikalar da gereklidir. $\mathrm{Bu}$ yönde politika geliştirebilmek için mevcut durumun gerçekçi bir şekilde tespit edilmesi gerekmektedir. İmalat sanayinde her bir alt sanayinin kendine has üretim yapısı ve özellikleri söz konusudur. Bu nedenle imalat sanayi ile ilgili olarak genel yaklaşımlarla tespitlerde bulunmak ve buna bağlı olarak politikalar geliştirmek yeterli ve doğru değildir. Her bir alt sanayi veya sektör ile ilgili olarak detaylı çalışma yapılarak mevcut durum ve sorunlar doğru olarak tespit edilmeli ve bunlara yönelik mikro düzeyde politikalar geliştirilmelidir. Bu yaklaşımla bu çalışmada, imalat sanayi alt sektörlerinden tekstil ve hazır giyim sektöründe ithal girdi kullanım düzeyi ve ithal girdi kullanım nedenleri araştırılmıştır. Araştırma alanı olarak tekstil ve hazır giyim sektöründe üretim ve ihracat yoğunluğu açısından lider iller arasında yer alan Denizli seçilmiştir. Denizli tekstil ve hazır giyim sektöründe üretim yapan 86 firmanın verilerine derinlemesine yüz yüze görüşme ve anket yöntemi kullanılarak ulaşılmıştır.

Firmaların üretimde kullandıkları girdiler hammadde, ara malı, makine ve teçhizat olmak üzere üç ana grupta değerlendirilmiştir. Hammadde grubunda (pamuk, elyaf, iplik) ithal kullanım payı oldukça yüksektir. Hammadde grubu genel olarak ele alındığında ithal kullanım payının nedenleri arasında ilk sirada ithal olanın daha ucuz olması gelmektedir. Yerli üretimin pahalı olmasının nedenleri arasında, üretim maliyetlerinin yüksekliği ve zaman içinde üretimin azalmasıyla fiyatların yükselmesi gösterilebilir. Firmaların üretimde kullandıkları ara mallarında ithalat payı oldukça düşüktür. Ara malları maliyetinin toplam üretim maliyetleri içindeki payının düşük olması ( $\%$ 4 $)$ firmaların bu alanda maliyet baskısı hissetmesinin önüne geçmektedir. Ayrıca bu alanda yurtiçi üretimin yeterli olduğu belirtilmiştir. Bu gibi nedenlerle firmaların büyük kısmı bu alanda ithal girdi kullanımına yönelmemektedir. Makine ve teçhizat grubunda ithal girdi kullanım payı ortalama \% 95 olarak hesaplanmıştır. İthal etme nedenlerinin başında ithal edilenin daha kaliteli olması ve yerli üretimin olmaması gelmektedir. Sonuç olarak, alan araştırmasının bulgularından hareketle Denizli tekstil ve hazır giyim sektöründe hammadde ve yatırım malları grubunda ithal girdi kullanım payı oldukça yüksek bulunmuştur.

Eldeki verilerle, ithal girdilerin firmaların değişken maliyetleri içindeki payı da tahmin edilebilir. Doğrudan girdi olarak kullanılan pamuk, elyaf ve iplikte ithal kullanım payı ortalama \% 67 olarak hesaplanmaktadır. Alan araştırmasından elde edilen veriler doğrultusunda, hammaddenin üretim maliyetlerindeki payının \% 39 olduğu bilindiğine göre, maliyetler içinde ithal hammadde payı \% 26'dır. Ara malı grubundaki ithalatın maliyetler içindeki payı göz ardı edilebilecek kadar $(\% 0,1)$ küçüktür. Buna karşın, enerji kullanımının da dolaylı olarak tamamen ithalat yoluyla $\left(\begin{array}{ll}\% & 10\end{array}\right)$ karşılandığı varsayıldığında maliyetler içindeki toplam ithal girdi payı \% 36 olarak hesaplanmaktadır. Bu bulgular, Türkan (2006), Saygılı vd. (2010) ve Özlale ve Karakurt (2012) çalışmalarının bulguları ile benzerlik göstermektedir. Bu çalışmalarda da analizler firma düzeyindeki verilerle yapılmış olup, genel bir bakış açısıyla, hesaplanan oranlar girdi-çıktı tabloları kullanılarak hesaplanan oranlardan yaklaşık \% 10-15 daha yüksektir. Dahası, bu çalışmaların bulgularının sektörlerdeki gerçek durumu yansıtma olasılığının daha yüksek olduğu ileri sürülebilir. Bu görüşün temelinde, bu çalışmalarda analizlerin alan araştırmalarından veya TÜİK vb. kuruluşlardan firma düzeyinde elde edilen verilerle yapılmış veya desteklenmiş olmasının yanı sıra, girdi-çıktı tablolarının güncel olmaması nedeniyle son dönemdeki gelişmelerin takip edilememesi veya girdi-çıktı tablolarındaki verilerin gerçeği tam olarak yansıtmama olasılığı yatmaktadır. Bu nedenle, alt sektörler düzeyinde hatta şehir/bölge özelinde her bir sektör için detaylı bir araştırma yapılarak gerçek ve güncel değerler ve sorunlar tespit edilmelidir. Ancak bu sayede sektörlere/bölgelere özgü sorunları giderici firma ve sektör düzeyinde gerçekçi politikalar üretilebilecektir.

İthal girdi kullanımının, Denizli tekstil ve hazır giyim sektörü örneğinde olduğu gibi mevcut koşullarda teknik olarak üretilemeyen girdilerle (makineler) birlikte belli bir dönem önce üretilen ancak maliyet ve fiyat baskıları nedeniyle üretmekten vazgeçilen (pamuk, iplik gibi) alanlara da yayılması ekonomi politikaları açısından düşündürücüdür. Dünya ekonomisinde Çin ve Güney Kore gibi bazı ülkelerde uygulanan sanayileşme politikaları sayesinde yıllar içinde daha teknoloji yoğunluklu girdiler üretebilir hale gelmiştir. Bu politikalar sayesinde literatür analizinde yer aldığ 1 gibi, örneğin Çin'de, yerel katma değer oranları zaman içerisinde yükselmiştir. Türkiye'de ise böyle bir gelişme yaşanmadığı gibi, hali hazırda ülke içinde üretilebilen birçok girdi ithal edilir hale gelmiştir. Böyle farklı örneklerle karşılaşılmasının arkasında, ekonomik hedeflerin seçimi, hedeflere yönelik uygun ekonomi 
politikalarının belirlenmesi ve istikrarlı bir şekilde uygulanması gibi faktörler ve bunların ülkelere göre farklılık göstermesi yer almaktadır. Eğer, ekonomi politikaları gözden geçirilip, hedefler ve araçlar revize edilmezse önümüzdeki yıllarda bu durumun daha derinleşmesi kaçınılmazdır. Dahası bu gelişmeler reel sektör krizini daha da derinleştirecektir.

$\mathrm{Bu}$ doğrultuda, hammadde grubuna yönelik yerli üretimi teşvik edici politikaların uygulanması önceliklidir. Çünkü bu gruptaki iyileştirmelerin, yenilik içerikli ürün üretimine ve sektörde kullanılan teknoloji yoğun girdilerin (makineler) üretimine göre istihdam, gelir ve diş ticaret bakımından etkileri daha doğrudan nitelikte olup, olumlu etkiler daha kısa zamanda ortaya çıkabilecektir. Ülkenin içinde bulunduğu işsizlik ve işgücünde nitelik sorunu, bu tercihi daha da rasyonel kılmaktadır. Hammadde grubuna yönelik yerli üretimi teşvik edici politikalara öncelik verilmesi diğer alanların ihmal edilmesini gerektirmemektedir. $\mathrm{Bu}$ seçim, sadece planlama ve zamanlama ile ilgili bir konudur.

\section{Kaynakça}

Akçomak, S. (2012). İşgücü Piyasasındaki Güncel Dinamikler: Teknoloji, Küreselleşme ve İthal Girdi Kullanımı, TEKPOL Working Paper Series, STPS-WP12/02, Science and Technology Policies Research Center, METU, Ankara.

Ayaş, N.(2017). Import Dependency of Sectors and Major Determinants: An Input Output Analysis, European Journal of Sustainable Development Research, 2(1), 116.

Aydoğuş, O., Değer, Ç., Tunalı Çalışkan, E. \& Gürel Günal G. (2015). An Application of the Hybrid Approach to Constructing Regional Input-Output Tables: Case of İzmir, Turkey, İktisat İsletme ve Finans, 30(348), 9-34.

Babahanoğlu, Y. (2015). Value-Added Content of Exports Consistent with Imported Intermediates: A Quantitative Analysis. Doktora Tezi. Ankara: İhsan Doğramacı Bilkent University Department of Economics.

Baldwin, R. (2006). Globalisation: the Great Unbundling(s), Globalisation Challenges for Europe and Finland, Secretariat of Economic Council.

Baldwin, R. (2009). Integration of the North American Economy and New-Paradigm Globalisation, CEPR Discussion Paper, No: 7523.

Blinder, S. A. (2009) How Many U.S. Jobs Might be Offshorable, World Economics, 10(2), 41-78.

Boratav, K. (2013). Emperyalizm, Sosyalizm ve Türkiye. 3. Basım, İstanbul: Yordam Kitap.

Chen, X., Cheng, L. K., Fung, K-C. \& Lau, L. J. (2004). The estimation of domestic value-added and employment induced by exports: an application to Chinese exports to the United States, Working Paper, Stanford University Department of Economics, California.
Çolak, Y. \& Terzioğlu, M. (2019). Türkiye İmalat Sanayi Alt-Sektörlerinde İhracat ile İthalat Arasındaki Nedensellik İlişkisi Üzerine Bir Araştırma, III. Uluslararast EUREFE Kongresi, Adnan Menderes Üniversitesi, Aydın.

Ersungur, Ş. M. \& Kızıltan, A. (2007). Türkiye Ekonomisinde İthalata Bağımlılı̆̆ı Girdi-Çıktı Yöntemiyle Analizi, Atatürk Üniversitesi Sosyal Bilimler Enstitüsü Dergisi, 9(1), 267-278.

Eşiyok, B. A. (2013). Türkiye Imalat Sanayinin Teknolojik Yapısı: Sürdürülebilir mi?. (Erişim: 12.08.2019), http://www.inovasyon.org/pdf/B.AliEsiyok.Imalat.San. TeknoYap\%C4\%B1.pdf.

Hummels, D., Ishii, J. \& Yi, K-M. (2001). The Nature and Growth of Vertical Specialization in World Trade, Journal of International Economics, 54, 75-96.

Konak, A. (2012) Ticarette Dışa Bağımlılık ve Türkiye'nin Dış Ticareti Üzerine Etkileri: 1980-2010 Ekonomik Analizi. Doktora Tezi. Sakarya: Sakarya Üniversitesi Sosyal Bilimler Enstitüsü.

Koopman, R., Wang, Z. \& Wei, S-J. (2012). Estimating Domestic Content in Exports When Processing Trade is Pervasive, Journal of Development Economics, 99(1), 178-189.

Kundak, S. (2015). Türkiye'de Imalat Sanayinin Ithalata Bağımlılı̆̆ının Analizi. Doktora Tezi. Afyon: Afyon Kocatepe Üniversitesi.

Özlale, Ü. \& Karakurt, A. (2012). Türkiye'de Tasarruf Açığının Nedenleri ve Kapatılması için Politika Önerileri, Bankacılar Dergisi, 23(83), 1-33.

Pamukçu, T. \& de Boer, P. (2000). A Structural Decomposition Analysisof Imports of Turkey (19681990). (Erişim: 09.10.2019), https://www.academia. edu/699050/A_structuraldecomposition_analysis_of_ imports_of_turkey_1968-1990.

Saygılı, Ş., Cihan, C., Yalçın, C. \& Hamsici, T. (2010). Türkiye İmalat Sanayiinin İthalat Yapısı. Türkiye Cumhuriyet Merkez Bankası, Çalışma Tebliği, No: 10/02, Ankara.

Şenesen, Ü. \& Günlük Şenesen, G. (2003). Import Dependency of Production in Turkey: Structural Change From 1970's to 1990's, Tenth Annual Conference of the Economic Research Forum (ERF), 16-18.12.2003.

Taymaz, E., Voyvoda, E. \& Y1lmaz, K. (2011). Uluslararası Üretim Zincirlerinde Dönüşüm ve Türkiye'nin Konumu. (Erişim: 22.07.2019), TÜSİADKoç Üniversitesi Ekonomik Araştırma Forumu, Ekonomik Araştırma Forumu Çalışma Raporları Serisi, EAF-RP/11-01,https://tusiad.org/tr/yayinlar/raporlar/ item/5878-uluslararasi-uretim-zincirlerinde-donusumve-turkiyenin-konumu.

Türkan, E. (2006). Türkiye'de Üretimin Ithalat ve Ihracat Bă̆ımlılı̆̆ı. (Erişim: 15.08.2019), TCMB Bünyesinde Yapılan Çalışmalar, https://www.tcmb.gov.tr/wps/wcm/ connect/fa56c108-d6c1-4668-b3ae-388f8450ef2a/ UretimdeDisTicaretBagimliligi.pdf?MOD=AJPERES\& CACHEID=ROOTWORKSPACE-fa56c108-d6c14668-b3ae-388f8450ef2a-m3fBal-. 
Türkiye Cumhuriyeti Strateji ve Bütçe Başkanlığ (TCSBB). (2019). Göstergeler, Ekonomik ve Sosyal Göstergeler, Dış Ticaret ve Ödemeler Dengesi, İthalatın Mal Gruplarına Göre Dă̆ılımı. (Erişim: 10.06.2019), http://www.sbb.gov.tr/ekonomik-ve-sosyalgostergeler/\#1540021488947-36394c03-3282.

Yalçın, F. C., Cebeci, T. \& Uras, Ö. (2015). Türkiye'de Sektörlerin Milli Ekonomiye Katkısı, TEDAM Araştırma Projesi-II, İstanbul Ticaret Üniversitesi-TiMEximbank Dış Ticaret Araştırma Merkezi, İstanbul.
Yentürk, N. (2004). Türkiye'de Uygulanan İktisat Politikalarının İhracatın İthalata Bağımlılığı Üzerindeki Etkileri: Girdi-Çıktı Tekniği İle Bir İnceleme. İ̧̧inde: F. Aral (Ed.), Gülten Kazgan'a Armağan, İstanbul: İstanbul Bilgi Üniversitesi Yayınları.

Yükseler, Z. \& Türkan, E. (2006). Türkiye'nin Üretim ve Dış Ticaret Yapısında Dönüşüm: Küresel Yönelimler ve Yansımalar, Ekonomik Araştırma Forumu Çalışma Raporları Serisi, TÜSIAD-Koç Üniversitesi Ekonomik Araştırma Formu, İstanbul. 